\title{
THE INTRODUCTION OF VACCINATION PRACTICE IN THE ORENBURG REGION IN THE EARLY XIX CENTURY
}

(C) 2017

\author{
Mifteeva Diana Maratovna, postgraduate student of Russian History Department \\ Orenburg State Pedagogical University (Orenburg, Russian Federation)
}

Abstract. The purpose of this work is to research the process of introduction of smallpox prevention in the Orenburg Region in the early 19th century. The author focuses the main attention on the organization and activity of subsidiary medical institutions - smallpox committees. The author shows the role of Free Economic Society, doctors, clergy, civil people in the development of smallpox prevention in the region. Based on the analysis of historical sources which are represented in the state archive of the Orenburg Region (fund 6 «the offices of Orenburg military governor») the author makes an attempt to detect the main cause of civil resistance in the region. The author used chronological, historical, retrospective and inquiry learning methods. The conducted research showed that in the 19th century in the Orenburg province there was a system of vaccine prevention of smallpox among the population despite the difficult sanitary and epidemiologic situation, lack of medical institutions and shortage of qualified medical personnel. The formation of this process started in the early XIX century. Thus, effective activities of the state and public organizations during this period let to lower the general illness rate and death rates from natural smallpox among the population in the Orenburg province.

Keywords: Orenburg Region; smallpox prevention; variolation; vaccination; folk medicine; healers; doctors; epidemic; anti-epidemic measures; smallpox committees; Free Economic Society; disease prevention; sanitary policy.

УДК 908

\section{РОЛЬ САМАРСКОГО И СИМБИРСКОГО ДВОРЯНСТВА В ДЕЛЕ ПООЩРЕНИЯ И ПОДДЕРЖКИ ОБРАЗОВАНИЯ НА РУБЕЖЕ ХІХ-ХХ ВЕКОВ} (C) 2017

\author{
Казанцева Светлана Генриховна, кандидат исторических наук, доцент кафедры философии \\ Самарский национальный исследовательский университет имени академика С.П. Королёва \\ (2. Самара, Российская Федерачия)
}

Аннотация. В данной статье рассматривается благотворительная деятельность дворянства Самарской и Симбирской губерний в конце XIX - начале XX века. В силу своего привилегированного сословного положения, губернские дворяне жертвовали свои капиталы, в первую очередь, на поощрение и поддержку образования как среди самих дворян, так и среди других сословий. Пожертвования направлялись в дворянские учебные заведения, такие как гимназии, кадетские корпуса, университеты, а также в учебные заведения для низших сословий: учительские школы, крестьянские школы и училища, ремесленные училища, учебные мастерские. В статье были проанализированы основные формы поддержки учащихся. Прежде всего, это учреждение и выплата именных и иных стипендий учащимся гимназий, университетов, кадетских корпусов, а также устройство и содержание учебных заведений и для самого дворянства, и для учащихся из других сословий. Нередко учащиеся таких заведений находились на полном пансионе за счет дворянства. Кроме того, дворяне были инициаторами создания благотворительных обществ, которые занимались материальной поддержкой учащихся, возглавляли попечительские советы при различных учебных заведениях. Изучение опыта дореволюционной России в деле поддержки образования помогает нам находить пути развития и поощрения учащихся в наши дни.

Ключевые слова: дворянство; купечество; образование; народное просвещение; благотворительность; благотворительные общества; университеты; гимназии; училища; студенты; сословные стипендии; город Самара; город Симбирск; Самарская губерния; Симбирская губерния.

В современном российском обществе как никогда актуальной становится проблема развития образования. Экономические реалии предполагают наличие как государственных, так и частных учебных заведений. В связи с этим встают вопросы материальной поддержки учащихся. Сейчас оплата образования в основном осуществляется самими учащимися и их близкими. Изучение опыта дореволюционной России в деле поддержки образования поможет нам найти пути развития и поощрения учащихся в наши дни, привлекая средства благотворителей или благотворительных обществ.

На рубеже веков, в связи с изменениями в экономической, политической и финансовой сферах России, вновь стала модной и актуальной тема образо- вания и народного просвещения. Российские реалии конца XIX - начала XX века требовали в достаточной мере образованных и просвещенных специалистов как на производстве в городах, так и в сельском хозяйстве в деревнях. Государство, несомненно, финансировало образовательные и просветительские учреждения. Например, его расходы по Министерству народного просвещения возросли с 1900 года почти в пять ра3, составив в 1913 году 14,6\% бюджетных расходов. [1, с. 4-5] Но в целом роль государства была достаточно скромной. Это видно из некоторых статей государственных ассигнований на 1900 год. Так, на устройство технических и ремесленных училищ предполагалось израсходовать 54 тыс. рублей, на стипендии и пособия студентам 
девяти университетов - 242 тыс. рублей, а также на борьбу с эпидемическими болезнями - 10 тысяч, на содержание некоторых музеев и библиотек - 121 тысячу рублей» [2, с. 14-15].

Без помощи частных лиц и общественных организаций российское образование в то время не могло развиваться достаточно быстро. Эта помощь оформлялась в виде благотворительной деятельности. Причем на образование и просвещение жертвовали средства люди из всех сословий тогдашней России: и дворяне, и купцы, и мещане, и крестьяне. Пожертвования были как частные, так и общественные, осуществлявшиеся через различные благотворительные организации.

В данной работе будет рассмотрена благотворительная деятельность Самарского и Симбирского дворянства на поприще поощрения и поддержки образования на рубеже XIX-XX веков.

Основные пожертвования дворян направлялись на устройство сословных учебных заведений и установление сословных стипендий, но и представители других сословий, желавшие получить образование, также получали денежную поддержку со стороны дворянства. К середине 90-х годов XIX века, по данным 28 обществ, на проценты от дворянских капиталов и в счет ежегодных сборов было учреждено 1889 стипендий (1558 мужских и 331 женских), 186 лиц получали пособия для подготовки к поступлению в учебные заведения [3, с. 170-171]. И все же эти пожертвования были довольно малы по сравнению, например, с купеческими. В то же время представители, и особенно представительницы «благородного сословия», охотно «украшали своим присутствием» попечительские советы различных благотворительных обществ, деньги на которые часто давало купечество [2, с. 14-15].

В 1870 году, после того как статс-секретарь К.К. Грот (бывший Самарский губернатор) ушел с должности директора департамента неокладных сборов, бывшими его сотрудниками был собран капитал в сумме 34800 руб. и обращен в процентные бумаги. Этот капитал был передан в ведение Министерства народного просвещения как неприкосновенный, а на проценты с него были учреждены именные стипендии К.К. Грота. Они выплачивались в различных мужских и женских гимназиях, где готовили учителей и учительниц сельских школ. К концу 90-х годов XIX века стипендиальный капитал имени К.К. Грота вырос до 50400 руб. [4, с. 65].

Согласно положению о стипендиях статс-секретаря К.К. Грота, гимназические стипендии предоставлялись преимущественно детям акцизных чиновников столичных и губернских гимназий. А стипендии в учительских школах предоставлялись только лицам крестьянского сословия и только уроженцам Самарской губернии, причем с условием, что стипендиаты были обязаны после окончания школы прослужить не менее трех лет в звании учителя или учительницы в одной из сельских школ Самарской губернии. С 1874 года, когда открылась Самарская учительская семинария, мужскими стипендиями статс-секретаря К.К. Грота пользовались 12 человек, вплоть до ее закрытия в 1887 году. Женские же стипендии выдавались четырем воспитанницам Самарской школы сельских учительниц [4, с. 66].
В разное время существовали четыре стипендии от Самарского дворянства в Неплюевском кадетском корпусе, две - в Симбирской классической гимназии и одна - в Саратовском институте благородных девиц [5, с. 23-24].

В Симбирской губернии дворянами также учреждались стипендии для бедных учеников: была учреждена стипендия имени графа Орлова-Давыдова, другие стипендии - имени И.А. Крылова, Н.М. Карамзина и пр. Выплачивались они детям дворян, обучавшимся в мужской и женской гимназиях города Симбирска [6].

В 1866 году симбирские дворяне создали капитал в пользу обучавшихся детей во второй Московской военной гимназии, который составлял 74500 рублей. Проценты с этого капитала - 2980 рублей - шли на выплату стипендий и оплату образования детям симбирских дворян, кроме того, в этой гимназии обучалось и два воспитанника от дворянства Самарской губернии [7].

В июне 1872 г. и в апреле 1874 г. в симбирской мужской гимназии были учреждены две стипендии имени директора училищ Симбирской губернии И.В. Вишневского. Сумма для стипендий, собранная по подписке, в 1872 г. составляла 410 рублей, а в 1874 г. - 461 руб. 5 коп. В августе 1872 года в этой же гимназии была учреждена стипендия Его Императорского Величества в знак посещения учебного заведения императором в августе 1871 г. Стипендиальный фонд исчислялся в 400 рублей [8].

Для поддержки студентов в Самаре было образовано благотворительное общество. Его история начинается 12 января 1871 года, когда Самарское Благородное собрание безвозмездно приняло воспитанников всех университетов, правоведов и лицеистов, которые собрались праздновать годовщину Московского университета. Тогда же самарской интеллигенцией было внесено предложение открыть общество поощрения высшего образования, которое открылось 25 февраля 1873 года. Инициаторами дела были А.И. Смирнитский, Г.И. Жуковский, Н.А. Мордвинов, С.О. Лавров и В.О. Португалов. Первые собранные ими 223 рубля были переданы тем выпускникам Самарской гимназии, которые нуждались в средствах для поступления в университет.

В уставе общества поощрения высшего образования была сформулирована цель - «путем благотворительности доставлять пособия таким лицам, которые, готовя себя к высшему образованию или продолжая оное, или же окончив курс в высшем учебном заведении, нуждаются в материальной поддержке, а именно: доставлять вспомоществование: нуждающимся ученикам и ученицам средних учебных заведений; ученикам, затрудняющимся по бедности поступить в вузы; в аналогичном положении ученикам духовной семинарии и лицам домашнего воспитания; нуждающимся студентам, имеющим по воспитанию и семейному положению связь с Самарской губернией; ученикам вузов, оказавшимся по возвращению в Самару в состоянии крайней нужды» [9, c. 270-271]. Членами общества могли стать все желающие вне зависимости от звания, но все же более активное участие в деятельности общества принимали дворяне и интеллигенция. 
В 1874 году общество содержало трех стипендиатов в Казанском университете, что составляло 470 руб. в год, а также выплатило единовременные пособия трем студентам и одному вольному слушателю Казанского университета; трем студентам Медико-хирургической академии и бывшему воспитаннику Самарской духовной семинарии, всего 330 руб. Кроме того, из средств общества выплачивались три постоянных пособия ученикам Самарской гимназии и два - единовременных, что составило 516 руб. [10, с. 300-301].

Деятельность общества поощрения высшего образования продолжала расширяться, основной капитал увеличивался год от года, и количество лиц, кому общество оказывало помощь и поддержку, росло. Большую роль в пополнении капитала общества играли частные пожертвования местных благотворителей, социальный состав которых был разнообразен. Наиболее крупные пожертвования делали представители купеческого сословия. Так, М.З. Курлина внесла 13000 рублей на создание трех стипендий имени ее покойного сына Д.Г. Курлина, А.В. Дунаева - 2000 рублей на создание стипендии имени Е.Н. Дунаевой. Крупные пожертвования были также сделаны А. фон Вакано - 1800 руб., И.Д. Ковригиным - 1200 руб., Е.И. Кириллова внесла 1000 рублей на создание стипендии имени Д.В. Кириллова. По подписке на учреждение именных стипендий средства поступили от А.П. Херувимова - 1450 руб., А.И. Смирнитского - 1266 руб., А.Н. Соболева - 900 руб., П.В. Алабина - 606 руб. и др. [11, с. 598-599].

Кроме частных лиц, благотворительную помощь обществу поощрения высшего образования оказывали и местные общественные организации. Например, Самарское губернское земское собрание для взноса на право учения беднейших учеников гимназии выделило 6000 руб., Самарское общество взаимного вспомоществования - 2000 руб., Общество врачей Самарской губернии выделило на стипендию имени В.А. Паршенского 564 руб., а Самарское Благородное собрание регулярно передавало специальный карточный сбор в пользу общества. Это позволило уже к 1875 году увеличить капитал общества до 2027 руб. 44 коп. и к трем стипендиям казанских студентов добавилась одна стипендия для студента Санкт-Петербургского университета, что вместе составило 533 руб. 31 коп. Всего же за время с 1873 по 1886 гг. общество поощрения высшего образования на стипендии студентам и другие пособия учащимся потратило 34776 руб. [12, с. 51-52].

Царское правительство старалось помогать и всесторонне поддерживать дворянство. Закон Николая II о воспитании и образовании дворянского юношества предписывал принять на иждивение казны устройство дворянских пансион-приютов и половину содержания его воспитанников, кроме того, для каждого дворянства учредить несколько стипендий в кадетских корпусах и принять на счет правительства половину стипендий в высших и средних учебных заведениях Российской империи, если дворяне пожелают их учредить. В ответ на это решение правительства Самарское дворянство постановило принять на себя половину расходов по содержанию пансиона в г. Самаре и стипендий, обложив для этой цели свои имущества ежегодным сбором до 8000 руб. Кроме того, в 1899 году в честь 100-летия со дня рождения А.С. Пушкина Самарское дворянство решило отпра- вить в Петербург на памятник поэту 500 рублей и учредить стипендию в университете и самарской гимназии имени А.С. Пушкина в размере 200 руб. ежегодно, если же ученик гимназии переходил в один из университетов страны, то стипендия ему не только сохранялась, но и увеличивалась до 400 руб. ежегодно [5, с. 21].

Кроме учреждения стипендий, дворяне открывали и свои учебные заведения. Одним из старейших в Самаро-Симбирском Поволжье было Елисаветинское училище, основанное дворянами Симбирской губернии в 1867 году. Финансировалось оно на проценты с неприкосновенного капитала, небольшое пособие от казны и частные пожертвования. В училище обучалось от 15 до 30 «казенноштатных» человек и от 10 до 15 - «своекоштатных» из дворянского сословия, за которых благотворители вносили плату по 120 руб. в год за каждого. Благотворителями «своекоштатных» учеников выступали прежде всего сами дворяне [13, с. 254-255].

Дворяне Самарской и Симбирской губерний жертвовали средства не только для своего сословия, но и основывали и содержали разного рода учебные заведения для представителей низших сословий. Так, графиня Ольга Ивановна Орлова-Давыдова, в девичестве Барятинская (1814-1876), открыла на свои деньги две школы - одну для крестьян, а другую для дворовых девочек. Первая была национальная чувашская в с. Тайдакове, а вторая - русская в с. Усолье. Эти учебные заведения были единственными на Самарской Луке после отмены крепостного права частными бесплатными школами для детей низшего сословия. В них детей обучали грамоте, Закону Божьему (в чувашской школе преподавание велось на родном языке), а также различным ремеслам, чтобы в будущем дети могли вести хозяйство и заниматься земледелием. Эти школы графиня О.И. Орлова-Давывова полностью обеспечивала вплоть до своей смерти в 1876 году. Кроме того, она оказывала поддержку многим деятелям российской культуры. О ней писали Тютчев, Аксаков и др. [14, с. 25-26].

С июня 1888 г. действовало благотворительное общество вспомоществования нуждающимся ученикам Симбирского ремесленного училища графа В.В. Орлова-Давыдова, находившееся в его поместье. В нем обучались грамоте и сельскохозяйственным ремеслам дети крестьян и служащих поместья графа.

Одним из известнейших благотворителей г. Симбирска был Михаил Васильевич Лебедев. В 1897 году он пожертвовал все свое состояние в количестве 66000 рублей на устройство ремесленного училища для круглых сирот с интернатом при нем [15]. Уже современники Лебедева считали его замечательной, но загадочной личностью. Он накапливал свой капитал в течение 45 лет, получая ничтожное жалование маленького чиновника, и вел подвижническую, в полном смысле слова, жизнь.

Родился М.В. Лебедев в 1821 году в семье дворянина. Обучался в гимназии, но закончить ее не смог. С 1840 г. находился на государственной службе в канцелярии губернатора писцом второго разряда. Затем перешел в строительную комиссию [16]. Как чиновник исправно получал за выслугу лет чины и награды. Уйдя в 1883 году после 43 лет службы в отставку, он определился в штат духовной консистории без жалования. А через 10 лет он пожертвовал 
капитал на открытие ремесленного училища. Главным условием жертвователя было назвать его «Ремесленное училище, основанное М.В. Лебедевым в 1893 году» [17]. Он стал его пожизненным попечителем. За это пожертвование Лебедеву было присвоено звание Почетного гражданина г. Симбирска и «разрешили иметь портреты его в зале Думы и в ремесленном училище».

Ремесленное училище им. М.В. Лебедева давало профессиональное образование круглым сиротам мужского пола. Мальчики от 11 до 14 лет обучались следующим ремеслам: столярному, сапожному, портняжному, а также живописи. Обучение длилось четыре года. Количество учащихся не превышало 32 человек. Все ученики находились на полном пансионе, для чего М.В. Лебедев каждый год вносил по 500 руб. Лучшим из выпускников, особенно тем, кто желал открыть свою мастерскую, училище оказывало материальную помощь в сумме не более 50 руб. на «первоначальное обзаведение» [18]. Кроме этого главного дела своей жизни, Лебедев с 1896 года занимал должность почетного блюстителя Симбирской Мариинской женской гимназии.

Еще одно заведение было открыто в Самарской губернии 30 июля 1911 года в селе Знаменском (Аксаково) Бугурусланского уезда. Это были учебные мастерские для крестьян, оборудованные самарским дворянством в родовой аксаковской вотчине для того, чтобы увековечить имя писателя С.Т. Аксакова. В них крестьянских детей обучали столярному, слесарному и кузнечному ремеслу, а также мастерские давали самим крестьянам возможность отремонтировать инвентарь или заработать денег в зимнее время года $[19$, с. 9-10].

Кроме денежных пожертвований и учреждения стипендий, дворяне помогали учебным заведениям книгами, учебными пособиями и т.д., жертвовали даже лес, землю, материал на строительство зданий.

И все же в материальном плане помощь дворянства была значительно меньше, чем пожертвования купечества или мещанства. Это было обусловлено всеобщим оскудением дворянства после отмены крепостного права, неспособности большей части дворян перестроить свои поместья на современный, буржуазный способ управления и хозяйствования. Но отрицать важную роль и участие поволжского дворянства в деле благотворительности и помощи образованию нельзя.

\section{СПИСОК ЛИТЕРАТУРЫ:}

1. Россия 1913 год. Статистико-документальный справочник / ред.-сост.: А.М. Анфимов, А.П. Корелин. СПб., 1995. 415 с.

2. Боханов А.И. Коллекционеры и меценаты в России. М., 1989. 192 с.

3. Корелин А.П. Дворянство в пореформенной России. 1861-1904. Состав, численность, корпоративная организация. М., 1979. 303 с.

4. Вестник благотворительности. Журнал Ведомства учреждений Императрицы Марии. СПб., № 1. 1897.

5. Чемодуров А.А. Краткая записка о деятельности Самарского дворянства за 50-летний период существования Самарской губернии. 1851-1901 гг. М., 1901. $124 \mathrm{c}$

6. Государственный архив Ульяновской области (далее-ГАУО). Ф. 76. Оп. 2. Д. 133. Л. 1-20.

7. ГАУО. Ф. 477. Оп. 1. Д. 22.

8. Симбирские губернские ведомости. 1872. 29 августа.

9. Адрес-календарь и памятная книжка Самарской губернии на 1874 год.

10. Алабин П.В. Двадцатипятилетие Самары, как губернского города: Историко-статистический очерк. Самара, 1877. 744 с.

11. Самарская область (география и история, экономика и культура) / сост. Э.Я. Дмитриева, П.С. Кабытов. Самара, 1996. 598 с.

12. Алабин П.В. Трехвековая годовщина города Самары. Самара, 1887. 215 с.

13. Материалы для географии и статистики России, собранные офицерами Генерального штаба. Симбирская губерния. СПб., 1868. Ч. 2.

14. «Усольская» коллекция графов ОрловыхДавыдовых. Каталог выставки. Самара, 1999. 35 с.

15. ГАУО. Ф. 76. Оп. 1. Д. 548. Л. 25-25 об.

16. ГАУО. Ф. 45. Оп. 3. Д. 45. Л. 27.

17. ГАУО. Ф. 45. Оп. 3. Д. 45. Л. 6.

18. ГАУО. Ф. 76. ОП. 1. Д. 581.

19. Памятная книжка Самарской губернии на 1911 год.

\section{SAMARA AND SIMBIRSK NOBILITY ROLE IN EDUCATION PROMOTION AND SUPPORT AT THE TURN OF XIX-XX CENTURIES}

\section{(C) 2017}

\section{Kazantseva Svetlana Genrihovna, candidate of historical sciences, associated professor of Philosophy Department Samara National Research University (Samara, Russian Federation)}

Abstract. The paper deals with the nobility charity of the Samara and Simbirsk provinces at the end of XIX - beginning of the XX centuries. The provincial nobles because of their privileged class status sacrificed their money to promote and support education among both the nobility and other classes. Donations were sent to the noble educational institutions such as school, cadet corps, universities, as well as to schools for the lower classes: teachers' schools, peasant schools and colleges, vocational schools, training workshops. The paper analyzes the main forms of support for students - establishment and payment of nominal scholarships to students of high schools, universities, military schools, content of education both for the nobility and for students from other classes. Students of such institutions were often on full board basis at the expense of the nobility. In addition the nobles were initiators of charitable societies, which were engaged in material support of students as well as led boards of trustees at various educational institutions. The study of pre-revolutionary Russian education support experience helps us to find ways to develop and encourage students nowadays.

Keywords: nobility; merchants; education; public education; charity; universities; high schools; colleges; students; class scholarship; Samara; Simbirsk; Samara province; Simbirsk province. 